\title{
An investigation of multicultural provisions of the Ethiopian education policy
}

\author{
Belete Mebratu \\ Medaille College, USA \\ belete.k.mebratu@medaille.edu
}

\begin{abstract}
This study is an investigation of the multicultural provisions in the Ethiopian education policy in light of promoting inclusive education. Content analysis, thematic categorization, and interpretive stance were used to analyze the data collected from the 1994 Ethiopian education policy document. The findings of the study indicate that the policy includes provisions that address the need to promote democratic cultures of equality, justice, unity and cooperation among peoples; equality and respect of diverse languages and linguistics groups; the promotion of gender awareness in the society; and the equality, tolerance and mutual coexistence among followers of different religions in the country.
\end{abstract}

\section{Introduction}

This study is aimed at the investigation of the multicultural provisions of the Ethiopian education policy. Specifically, the purpose of the present study is to investigate whether or not the 1994 education policy of Ethiopia addresses diversity related expectations and directives that can promote multicultural education in the country. The study explores the multicultural messages addressed in the policy in the context of the diversity of the Ethiopian societies.

Ethiopia experienced a change of government in 1991 that led to reforms in the education system of the country. The educational reforms include a new education policy, decentralization of educational administration, new school curricula, and the use of vernacular languages of nationalities as media of instruction.

Education in Ethiopia will do more good if it is based on learning experiences that promote the idea of respect, tolerance, mutual understanding and peaceful coexistence. This calls for an educational practice that offers school children with the opportunities to appreciate their differences, while enabling them to acquire the skills, attitudes and knowledge essential for making a living within diversities. In this regard, the recent educational reform efforts in Ethiopia need to be measured, among others, by the extent to which they address cultural pluralism, mutual coexistence and unity within diversity. The Ethiopian education policy of 1994 is a relevant area of study for its inclusiveness and responsiveness to diversities through the provision of expectations and directives about multicultural learning experiences.

\section{Review of Literature}

The present study is based on the study of multicultural education addressed in a national education policy provisions in Ethiopia. The study explores whether the Ethiopian education policy provides expectations and directives for the promotion of multicultural education in the country. This study, therefore, is situated in the argument that multicultural education requires revising the structural, procedural, substantive, and evaluative components of the educational 
enterprise to reflect the social, cultural, ethnic, racial, and linguistic pluralism of a given society (Gay, 1995).

The study is framed in terms of the understanding of multicultural education involving approaches that promote the understanding of the ethnic groups' cultures, histories, and contributions, and enabling students become multicultural in their attitudes, values, beliefs, and behaviors (Bennett, 1995). This requires, according Banks (1992), among other measures, reforms of educational policies. The study is informed by the perspective of the advancement of multicultural educational practices through the inclusion of such expectations and directives in an education policy that frames the planning and implementation of instructions in classrooms. By studying the national education policy of Ethiopia, therefore, it can be made known whether the policy demonstrates commitment to the promotion of multicultural education in the schools of the nation.

Multicultural education addresses the issues of cultural, ethnic, racial, religious, gender and other forms of diversity and help school children learn about others. While focusing on cultural pluralism and ethnic diversity as its subjects of studies, it encounters negativity and builds up positive images, mutual awareness, and tolerance among groups (Banks, 1990, 1995; Gay, 1994; Nieto, 1992; Sleeter, 1995). Pedagogically, multicultural education encourages better learning in the context of diverse students' background (Hale-Benson, 1982; Shade, 1989; Spring 2000). In milieu of the diversity of the Ethiopian society, good citizenship calls for citizens' competence in the appreciation of differences, tolerance, respect, and positive attitudes across cultures. Efforts made to address such values at a level of an overarching Ethiopian education policy contribute to the relevance of the reforms to vital need of mutual co-existence and harmony in the country.

In the context of diversity, policy provisions of multicultural messages such as peaceful management of differences, tolerance, respect and mutual understanding as well as the concepts of liberty, equality, justice, and moral values are relevant subjects of study in multicultural education (Banks, 1990; Bennett, 1990; DiPardo \& Fehn, 2000). Aspects of democratic culture that the new education policy intends to disseminate among the Ethiopian society are viewed as new inputs into the recent reform in the education system of the country (Negash, 1996). These learning experiences can be cultivated among the new generation of Ethiopia through educational practices that are multicultural in their design and implementation. Reports on the achievements of educational developments in Ethiopia indicate that the educational reforms in the country aim at promoting democratic cultures through the education of civic minded citizens (UNESCO, 2004).

\section{Research Question}

The purpose of this study is to investigate the expectations and directives provided in the Ethiopian education policy that can promote multicultural learning experiences in the schools of the nation. Specifically, the study explores whether or not the policy includes multicultural educational provisions and the messages communicated in the provisions. The study is guided by the research question: What are the multicultural education provisions included in the Ethiopian education policy? 


\section{Materials}

\section{Methodology}

The present study is based on the analysis of the contents of the documents of the 1994 education policy of Ethiopia.

\section{The 1994 Education Policy}

The new Ethiopian education policy was put into effect in March 1994. The Ministry of Education (MOE), under the then Transitional Government of Ethiopia (TGE), took the responsibility in organizing task forces for the development of the policy. The policy document is categorized into different areas of the education system of the country.

The introduction deals with the problems of the education system and the necessity of this policy to search for the solutions. The second part deals with educational objectives and is categorized into two subsections of general and specific objectives. Part three is devoted to the educational strategies: curriculum, educational structure (levels of programs), educational testing, teachers' affairs, education and language, integration of education with research and development, educational technology, educational leadership and administration, and educational financing. The last part of the policy is a section on areas of priority. This is a federal policy with impacts on the subsequent reforms in the various aspects of the education system nationwide including the development of curriculum guides, syllabi, teachers guide, and textbooks.

\section{The Interpretation and Analysis of Data}

In the present study, documentary content analysis was employed to analyze the policy document for its responsiveness toward diversity issues in education. Content analysis is relevant to the present study since it is used to analyze educational documents to make inferences about their message (Gustafson, 1998). It is the method of drawing conclusions from text (Weber, 1990), involving procedures of the selection of the unit of analysis, category construction, sampling of contents, and coding the samples (Stemple \& Westley, 1981).

The units of analysis, in this study, are words, phrases, statements in the documents of the education policy. The words, phrases or statements in the policy are included in the analysis as long as they relate or refer to the factors of diversity of the study such as ethnicity, gender, linguistics and religion. Words and sentences in articles, sections, topics, and paragraphs are examined in search of expressions that deal with the diversity factors of the study. Then, it is followed by the interpretation of the meanings and messages channeled such as equality, tolerance, respect, dealing with diversities, appreciation of differences, mutual understanding, conflict management and resolution, and other related themes.

Thematic categorization and interpretive stance were employed to develop patterns of the messages conveyed in the texts of the study. The personal accounts of the writer of this paper as teacher educator, textbook writer, and membership in national curriculum teams during the time of the introduction and implementation of the new education policy have been instrumental in the conceptualization and undertaking of this study.

\section{Findings}


This section presents the multicultural provisions and expectations in the document of the 1994 education policy of Ethiopia. The multicultural provisions and expectations of the policy are presented below. The provisions and expectations of the policy are organized in the areas of democratic cultures, language, gender, and religion related themes.

\section{Multicultural Provisions in the Policy: Expectations and Directives}

\section{Democratic cultures}

The 1994 education policy document begins with an introduction that briefly summarizes the various problems of education in the country, and the need for this policy as part of the efforts in overcoming the problems. The section also introduces the different parts of the policy.

In terms of multicultural provisions, the Introduction section of the policy states, "Education...plays a role in the promotion of respect for human rights and democratic values, creating the condition for equality, mutual understanding and cooperation among people" (p. 1). This policy provision appears to attach value and role to education in the promotion and advancement of respect and tolerance among the people of Ethiopia. The policy statement expects the attainment of mutual understanding, equality, and cooperation in and through the process of education. This statement, further, seems to assume and recognize the conditions of diversity as it considers the issues of equality, mutual understanding, and cooperation among the Ethiopian society.

The General Objectives section of the education policy reiterates the multicultural expectations observed in the Introduction. Article 2.1.3 of the General Objectives calls for "Bringing up citizens who respect human rights, stand for the well-being of people, as well as for equality, justice and peace, endowed with democratic culture and discipline" (p.7). Likewise, the statements of the Specific Objectives of education in the policy have relevance to multicultural education. Article 2.2.9 enshrines "To provide education that promotes democratic culture, tolerance and peaceful resolution of differences and that raises the sense of discharging societal responsibility" (p.10). This expectation is further reinforced by the provision in Article 2.2.10 that stipulates "To provide education that can produce citizens who stand for democratic unity, liberty, equality, dignity and justice, and who are endowed with moral values" (p.10).

The statements of intentions in the objectives of education in the policy emphasize the issues of human rights, democratic culture, discipline, justice, equality, and wellbeing of others that are areas of interest for studies in multicultural education.

\section{Language}

The education policy contains provisions that deal with matters of language as medium of instruction at primary schools. The policy justifies the use of vernaculars in education in terms of rights as well as pedagogical advantages. The policy, in Article 2.2.12, states the recognition given to vernacular languages as media of instruction in schools. As part of the specific objectives of education in the country, the article intends "To recognize the rights of nations/nationalities to learn in their language...." (p.10). This provision has further been reinforced in the Language and Education section of the policy stated in Article 3.5.1. The article points, "Cognizant of the pedagogical advantage of the child in learning in mother tongue and the rights of nationalities to promote the use of their languages, primary education 
will be given in nationality languages" (p.13). This is a change compared to the former practice of using one national language as the medium of instruction for primary education nationwide.

Provision of the right to use vernaculars for education is one form of multicultural education. By doing so, the policy includes intentions that relate to multicultural education in the area of language.

\section{Gender}

The 1994 Ethiopian education policy addresses gender related problems in the country and calls for the need to change societal biases and stereotypes through education. The policy assumes that women can contribute to development endeavors, and the policy intends that this attitude has to be cultivated in the society through the process of education. This intention is stated in Article 2.2.13 of the policy as "To gear education towards reorienting society's attitudes and values pertaining to the role and contribution of women in development" (p.11). This statement is part of the Specific Objectives of education included in the policy. Moreover, the section of the policy that deals with Curriculum also requires that the preparation and development of curriculum and textbooks need to consider matters related to gender. Article 3.1.3 states "...ensuring that the curriculum developed and textbooks prepared at central and regional levels...give due attention to...gender issues" (p.12).

The education policy has paid attention to diversity matters in terms of gender. Such provisions are relevant given the patriarchal traditions in Ethiopian cultures. Gender related consideration in the new educational reform is vital to enhance the level of participation and representation of girls and women in education and beyond. The responsiveness of the educational reform to diversity factor of gender is an area of interest in multicultural education.

\section{Religion}

In matters of religion, the 1994 Ethiopian education policy requires in Article 2.2.7 that schools should provide secular education in the country. This appears to be a policy of a uniform treatment of religions across the board with no single religion being part of the school curriculum at the exclusion of others. On the other hand, however, the multicultural values such as respect, tolerance, equality, and conflict resolution and management, which are deemed important in the policy, can contribute to the promotion of coexistence among the followers of different religions in the country.

Generally, the 1994 Education policy of Ethiopia addresses multicultural expectations and directives in education in terms of promoting tolerance, mutual understanding, peaceful conflict resolution and management, equality, justice, liberty, dignity, moral values, democratic culture, and respect for human rights.

\section{Conclusion}

This study analyzed the responsiveness of the 1994 education policy of Ethiopia in terms of its provisions of multicultural learning expectations and directives. The education policy document expects that education should play the role of promoting respect for human rights, equality, mutual understanding, and cooperation in its introduction section. The policy specifies multicultural educational intentions in its general and specific statements of objectives of education in the country. Respect, equality, justice, democratic culture, and 
discipline are included to be among the learning outcomes of the educational processes. In its objectives, the policy considers the cultivation of tolerance, peaceful resolution of differences, standing for democratic unity, dignity, and moral values to be the frameworks for the planning and implementation of education in the country. In addition, the policy states the rights of the child to learn in vernacular language. In relation to gender issues, the policy states the need to reorient the society about the role of women in development efforts. Regarding religion, the policy indicates that education is secular in the country.

The policy document studied in the present study addresses issues of diversity that have bearings to the promotion of multicultural education in the Ethiopian schools. Such provisions of multicultural education can contribute to the advancement of the culture of civil society in the country. Further studies, however, are essential to illuminate on the inclusions of such policy provisions in textbooks and other curricular materials, and the classroom implementations of the intentions in the schools of the nation.

\section{References}

Banks, J. (1995). The historical reconstruction of knowledge about race: Implications for transformative teaching. Educational Researcher, 24(2), 15-25.

Banks, J. (1990). Citizenship education for pluralistic democratic society. The Social Studies, 81, 210-214.

Banks, J. (1992). A curriculum for empowerment, action, and change, In K.A. Moodley (Ed.), Beyond multicultural education: International perspectives (pp. 154-170). Calgary, Alberta: Detselig Enterprise.

Bennett, C. (2001). Genres of research in multicultural education. Review of Educational Research, 71(2), 171-217.

Bennett, C. (1995). Comprehensive multicultural education: Theory and practice $\left(3^{\mathrm{rd}} \mathrm{ed}.\right)$. Boston: Allyn \& and Bacon.

DiPardo, A. \& Fehn, B. (2000). Depoliticizing multicultural education: A return to normalcy in a predominantly white high school. Theory and Research in Social Education, 28(2), 170-192.

Gay, G. (1995). Curriculum theory and multicultural education, In J.A. Banks \& C.M. Banks (Eds). Handbook of research on multicultural education(pp. 25-43). New York: Macmillan Publishing.

Gay, G. (1994). A synthesis of scholarship in multicultural education: Urban ducation Monograph Series. Center for Multicultural Education at the University of Washington-Seattle.

Gustafson, N. (1998). Content analysis in the history class. The Social Studies, 89, 29-34.

Hale-Benson, E. (1982). Black children: Their roots, culture and learning styles. Baltimore: John Hopkins University Press.

Huerta, C. (1998). Barriers to the implementation of multicultural education in a secondary teacher education program. The High School Journal, 82(3), 150- 164.

Hursh, D. (1997). Multicultural social studies: Schools as places for examining and challenging inequality. In E.W. Ross (ed), Social Studies Curriculum: Purposes, problems, and possibilities (pp. 107-119). State University of New York Press, Albany.

Negash, T (1996). Rethinking education in Ethiopia. Upssala, Sweden: Nordiska Afrikainstitutet. 
Neito, C. (1992). Affirming diversity: The sociological context of multicultural education.

White Plains, NY: Longman, Inc.

Neito, C. (2002). Language, culture, and teaching: Critical perspectives for a new century.

New Jersey: Lawrence Erlbaum Associates, Publishers.

Shade, J. (1989). Culture, style and the educative press. Springfield, III. :Charles C. Thomas.

Sleeter, E. (1995). An analysis of the techniques of multicultural education. In Banks, J. \&

Banks, C. (EDS), Handbook of Research on Multicultural Education (pp. 81-

94). NY: Macmillan Publishing.

Spring, J. (2000). American education ( $9^{\text {th }}$ ed.). NY: McGraw-Hill Company, Inc.

Stemple, G. \& Westley, B. (1981). Research methods in mass communications. Englewood Cliffs, NJ. : Prentice- Hall Inc.

Torres-Guzman, M. \& Carter, R. (2000). Looking at self as the critical element for change in multicultural education: Pushing at the seams of theory, research, and practice. Teachers College Record, 102 (6), 949-52.

Transitional Government of Ethiopia (TGE). (1994). The training and education policy of Ethiopia. Addis Ababa, Ethiopia: Birhaninaselam Printing Press.

UNESCO (2004). Report on the development of education in Ethiopia to the UNESCO international conference on education, September 8-11, Geneva, Switzerland.

Weber, P. (1990). Basic content analysis ( $2^{\text {nd }}$ ed.). Newbury Park, CA: Sage. 